JOURNAL OF APPLIED SMART ELECTRICAL
NETWORK AND SYSTEMS (JASENS)
ISAS

\title{
Implementasi Neural Network Untuk Kendali Gerak Mobile Robot Pembasmi Hama
}

\author{
Dadi Setiadi ${ }^{1}$, Pola Risma ${ }^{2}$, Tresna Dewi ${ }^{3}$,RD Kusumanto ${ }^{4}$, and Yurni Oktarina ${ }^{4}$ \\ $1,2,3,4,5$ Electrical Engineering Department, Politeknik Negeri Sriwijaya \\ 1dadis129@gmail.com, 2polarisma@polsri.ac.id, ${ }^{3}$ tresna_dewi.ac.id*, \\ 4manto_6611@yahoo.co.id, 5yurni_oktarina@polsri.ac.id
}

\begin{abstract}
The agricultural sector is one of the most important economic sectors for Indonesia. However, agriculture itself is accompanied by a number of problems, one of which is pests that attack crops and cause crop failure. The use of robotics in agriculture can now overcome the limited capacity of farmers to monitor large land areas. Using an RC robot that can be controlled automatically via a cell phone monitor screen, human work is greatly facilitated. Artificial intelligence is implanted into a robot to improve the performance of an agricultural robot. This paper discusses designing a pest spraying robot with Neural Network applications for effective and efficient control inputs. The feasibility of the proposed method is proven by simulation conducted in Neuroph Studio and MobotSim. The simulation results show that neural network applications can effectively manage mobile robot movements with an error value of less than 0.1 to avoid the obstacles they encounter to reach the target.
\end{abstract}

Keywords: mobile robot, neural networks, motion control

\begin{abstract}
Abstrak
Sektor pertanian adalah salah satu sektor perekonomian yang penting bagi Indonesia. Namun, pertanian itu sendiri dibarengi dengan berbagai masalah salah satunya adalah hama yang menyerang tanaman dan dapat mengakibatkan gagal panen. Terbatasnya kemampuan petani untuk memantau lahan yang luas kini dapat diatasi dengan aplikasi robotika pada pertanian. Dengan menggunakan robot RC yang dapat dikontrol secara otomatis melalui layar monitor phone cell akan sangat memudahkan pekerjaan manusia. Kecerdasan artifisial ditanamkan pada robot untuk meningkatkan performa robot pertanian tersebut. Makalah ini membahas desain robot penyemprot hama dengan aplikasi Neural Network yang bertujuan untuk mendapatkan input kontrol yang efektif dan efisien. Untuk membuktikan efektivas, metode yang diajukan, pengujian dilakukan dalam program simulasi bernama Neuroph Studio dan MobotSim. Hasil simulasi menunjukkan aplikasi neural network dapat mengatur pergerakan mobile robot efektif dengan nilai error kurang dari 0,1 untuk menghindari rintangan yang dilewati nya untuk sampai ke target yang dituju.
\end{abstract}

Kata kunci: mobile robot, neural networks, motion control

Diterima Redaksi: 04-06-2020 | Selesai Revisi : 11-06-2020 | Diterbitkan Online : 30-06-2020

\section{Pendahuluan}

Indonesia merupakan negara agraris, peranan sektor pertanian yang sangat penting dalam mendukung perekonomian nasional, terutama sebagai bahan pangan, sandang, dan papan bagi segenap penduduk serta penghasil komoditas ekspor non migas untuk menarik devisa. Namun, ada persoalan pokok yang harus dihadapi para petani dalam memproduksi hasil dari lahan pertanian salah satunya adalah gagal panen akibat serangan hama pada tumbuhan tersebut. Umumnya petani dalam mengatasi serangan hama tersebut masih menggunakan alat konvensional.

Saat ini kemajuan teknologi berkembang semakin pesat salah satunya teknologi dibidang robotika. Kemajuan ini dimanfaatkan pada dunia industri dengan banyak penggunaan robot tersebut. Fungsi robot dalam dunia industri pada umumnya ditujukan untuk menggantikan peran manusia dalam melaksanakan tugas-tugas yang membutuhkan tenaga yang besar/kuat, yang memerlukan ketelitian yang tinggi dan yang mengandung resiko tinggi terhadap keselamatan manusia [1][2]. Salah satu jenis robot yang paling banyak aplikasinya adalah mobile robot karena robot jenis ini mampu bergerak cepat di bidang yang terstruktur maupun tidak terstruktur, baik sebagai robot tunggal maupun robot berkelompok [3-8]. Pada bidang pertanian dapat menerapkan kemajuan teknologi ini dengan mobile robot pembasmi hama. Mobile robot ini bertujuan untuk membantu para petani dalam mengatasi masalah akibat serangan hama sehingga dapat memaksimalkan hasil pertaniannya.

Salah satu hal yang penting dalam perencanaan dan pembuatan pada mobile robot ini adalah masalah kontrol 
gerak. Kontrol gerak yang dimaksud terdiri dari perencanaan gerak untuk menghindari rintangan dan pengambilan keputusan pergerakan untuk mencapai target yang dituju ketika diterapkan secara otomatis dalam lingkungan yang tidak tentu [3-8]. Pengontrol gerak mobile robot ini membutuhkan algoritma cerdas diantaranya seperti logika fuzzy [9-16], neural network [16-21], dan algoritma genetika [22].

Mobile robot ini berbasis Arduino dan Raspberry $P i$ dengan menggunakan sensor ultrasonik dan modul kamera Raspberry Pi. Mobile robot ini menggunakan metode neural network sebagai algoritma cerdas. Dengan menerapkan neural network ini membuat proses pembelajaran algoritma akan membantu dalam mengatur data, memprediksi keluaran dan meminimalkan kesalahan dan akhirnya menciptakan sistem otak robot untuk memutuskan jalan terbaik untuk gerak. Data yang diperoleh dari sensor jarak yang berguna untuk mendapatkan pelacakan lintasan yang efektif. Sehingga kombinasi antara sensor jarak dan neural network akan meningkatkan efisiensi dalam memutuskan jalur terbaik untuk mendapatkan target yang lebih cepat karena otak terpasang [2].

\section{MetodePenelitian}

Agar alat dan keseluruhan sistem dapat terealisasi sesuai dengan rencana dan target maka dibuatlah beberapa kegiatan pelaksanaannya, yaitu:

\subsection{Blok Diagram}

Blok diagram merupakan salah satu bagian penting dalam perancangan suatu mobile robot. Cara kerja keseluruhan mobile robot yang akan dibuat dapat dilihat pada (Gambar 1) sehingga keseluruhan blok diagram akan menghasilkan suatu sistem yang dapat difungsikan atau dapat bekerja.

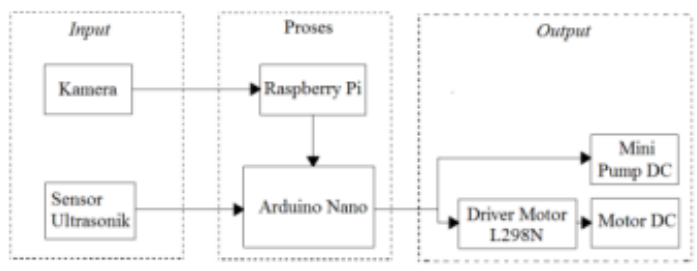

Gambar 1 Blok Diagram

Penjelasan pada setiap gambar blok diagram (Gambar 1) diatas, yaitu:

\section{Kamera}

Pada rancang bangun alat ini. Jenis kamera yang digunakan adalah modul kamera Raspberry Pi. Kamera ini berfungsi untuk mengambil gambar dengan kualitas high definition memiliki resolusi asli dari 5 megapixel, dan memiliki lensa fokus tetap di papan.

2. Sensor Ultrasonik
Sensor ini berfungsi untuk mengukur jarak antara halangan dan objek yang akan dituju di depan mobile robot. Pada rancang bangun alat ini terdapat 3 buah sensor ultrasonik dibagian depan base mobile robot dengan posisi sensor berada kiri, tengah, dan kanan dimana untuk posisi kanan dan kiri membentuk sudut masingmasing sebesar $45^{\circ}$.

3. Raspberry $P i$

Raspberry $P i$ berfungsi sebagai pengontrol kamera untuk mendapat acuan posisi suatu objek dari apa yang dilihat oleh kamera dan memprosesnya untuk input trigger mikrokontroler pengontrol driver motor.

4. Arduino Nano

Arduino nano berfungsi untuk menerima data jarak yang dikirim oleh sensor ultrasonik dan data koordinat warna yang dikirim oleh Raspberry Pi melalui sambungan kabel USB dengan komunikasi serial secara langsung lalu data yang diterima ini diproses untuk menentukan operasi pergerakan menggunakan motor DC dan penyemprotan pestisida menggunakan mini pump DC.

5. Mini Pump DC

Mini pump berfungsi sebagai pengontrol atau penyemprot pestisida dari tempat penyimpanan di mobile robot.

6. Driver Motor L298N

Driver motor L298N berfungsi mengendalikan gerak atau kecepatan motor DC pada mobile robot. Pada rancang bangun alat ini terdapat 3 buah driver motor dimana 1 driver motor untuk mengendalikan 2 buah motor DC.

7. Motor DC $12 \mathrm{~V}$

Motor DC 12V berfungsi sebagai pengerak dari mobile robot.Pada rancang bangun alat ini terdapat 6 buah motor DC

\subsection{Desain Mobile Robot}

Mobile Robot yang digunakan dalam makalah ini adalah mobile robot $6 \mathrm{wd}$ ditunjukkan dalam (Gambar.2). Jenis robot ini biasanya diterapkan di berbagai lintasan dengan 6 motor DC sebagai penggerak dengan menggunakan suspensi agar pergerakkan mobile robot stabil.

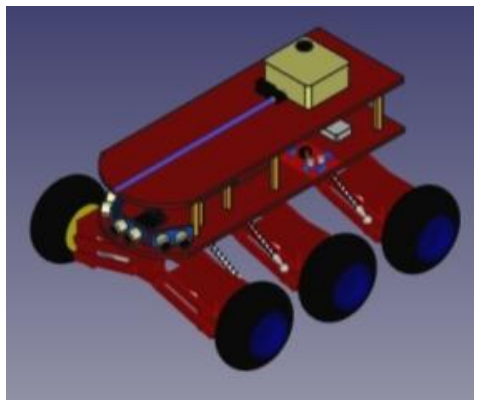

Gambar 2 Desain Mobile Robot

Posisi dan orientasi mobile robot pada Gambar 2 dirumuskan dengan : 


$$
q i=[x i, y i, \varnothing i]^{T}
$$

Dimana $x i$ dan $y i$ merupakan sumbu $X$ dan sumbu $Y$ dan $\emptyset i$ adalah orientasi mobile robot terhadap sumbu $Z$. Kecepatan robot adalah :

$$
v=\left[v_{m 1}, v_{m 2}\right]^{T}
$$

Dimana $v_{m 1}$ dan $v_{m 2}$ merupakan kecepatan motor kiri dan kanan. Kontrol input yang diterapkan pada mobile robot adalah :

$$
\mu=\frac{R}{2}\left(\dot{\theta}_{r}+\dot{\theta}_{l}\right)
$$

Dimana di mana $\dot{\theta}_{r}$ dan $\dot{\theta}_{l}$ merupakan orientasi roda kanan dan kiri. Kecepatan sudut dirumuskan dengan:

$$
\omega=\frac{R}{2 L}\left(\dot{\theta_{r}}-\dot{\theta}_{l}\right)
$$

Dimana $\dot{\theta}_{r}$ dan $\dot{\theta}_{l}$ adalah kecepatan sudut roda kanan dan kiri masing-masing. Selama pergerakan mobile robot, sensor mendeteksi rintangan dan objek yang ingin dituju agar memberikan jarak minimum yang pasti sebagai pertimbangan input ke pengontrol untuk mendapatkan kemudi mobile robot dan berpengaruh dengan kecepatan mobile robot $\left(v_{m 1}\right.$ dan $\left.v_{m 2}\right)$. Dalam makalah ini, mobile robot diasumsikan hanya bergerak maju menghindari rintangan yang ada di depannya dan menuju target tanaman yang disemprot pestisida tanpa slipping dan skidding [3]. Kecepatan gerak robot untuk mencapai target menjadi hal yang penting melihat performansi mobile robot. Dengan mengurangi atau memperkecil nilai error yang terjadi pada mobile robot maka efektivitas metode yang digunakan benar.

\section{Hasil dan Pembahasan}

\subsection{Simulasi Neural Network}

Dalam penelitian ini, jenis neural network yang digunakan adalah Multi Layer Perceptrons (MLP). Multi layer perceptrons adalah jenis neural network yang paling populer digunakan pada penelitian lain, menerapkan pengontrol feed-forward yang memiliki kemampuan untuk memperkirakan apa pun kelas fungsi umum, seperti fungsi kontinu dan terintegrasi [7].

Pada (Gambar 3) menunjukkan bahwa desain multi layer perceptrons yang digunakan pada penelitian ini yaitu tiga input layer (In 1, In 2, In 3) yang merupakan tiga sensor jarak (depan, kanan, kiri). Lima neurons di hidden layer, dua neurons di output layer (Out 1, Out 2) sebagai menandakan bahwa motor kiri dan motor kanan. Dan ada dua bias input neurons yang dihubungkan ke layer 1 dan layer 2. Simulasi yang digunakan untuk percobaan neural network dalam makalah ini adalah aplikasi Neuroph studio.

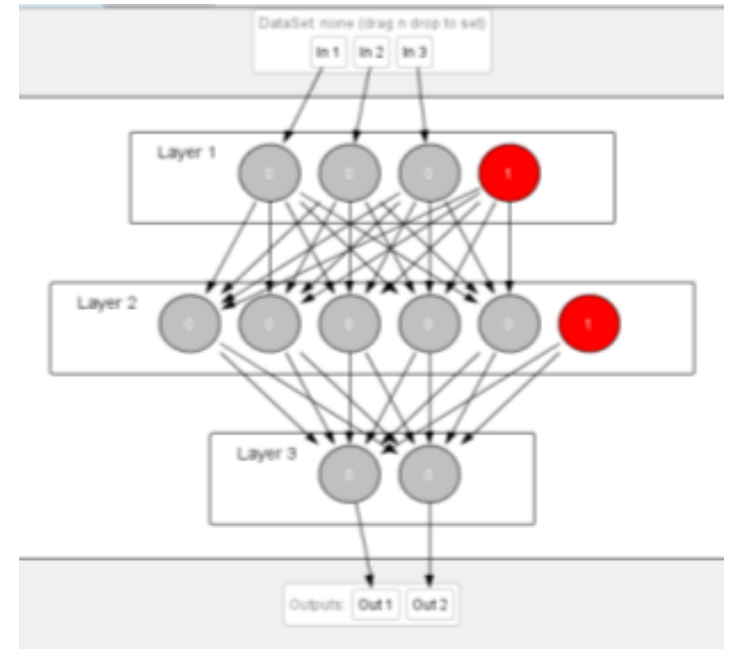

Gambar 3 Desain multi layer perceptrons

Sebelum pelatihan neural network dilakukan perlu beberapa parameter lain ditetapkan seperti : learning rate $=0,2$, Momentum $=0,7$, learning algorithm $=$ back propagation, Bias input $=1$, connection weights $=$ randomly assigned. Neural network akan menghasilkan gerakan roda untuk memindahkan robot ke kanan atau kiri. Pada (Gambar 4) memperlihatkan data training yang digunakan untuk proses training neural network. Data training ini dibuat sama dengan yang dipakai untuk data pengujian robot.

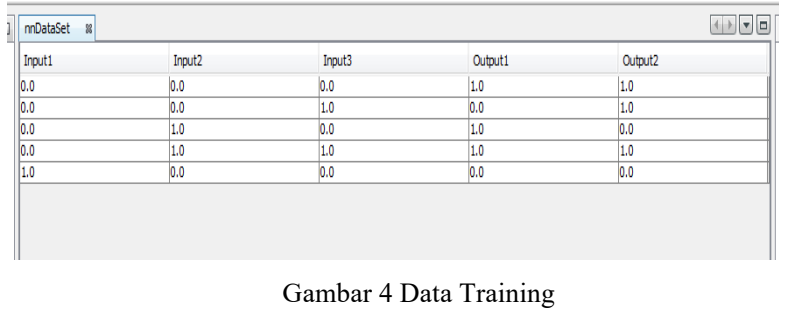

Hasil simulasi pada (Gambar 5a-d) memperlihatkan proses training neural network. Pada (Gambar 5a) memperlihatkan In 3 (sensor jarak kiri) ber nilai 1 atau mendeteksi ada rintangan maka hasil prediksi nilai output layer menggerakan motor untuk memindahkan robot ke kanan. Pada (Gambar 5b) memperlihatkan In 2 (sensor jarak kanan) ber nilai 1 atau mendeteksi ada rintangan maka hasil prediksi nilai output layer menggerakan motor untuk memindahkan robot ke kiri. Pada (Gambar.5c) memperlihatkan In 2 dan In 3 (sensor jarak kanan dan kiri) ber nilai 1 atau mendeteksi ada rintangan maka hasil prediksi nilai output layer menggerakan motor untuk robot berjalan maju. Pada (Gambar 5d) memperlihatkan In 1 (sensor jarak depan) ber nilai 1 atau mendeteksi ada rintangan maka hasil prediksi nilai output layer menggerakan motor untuk robot stop. 


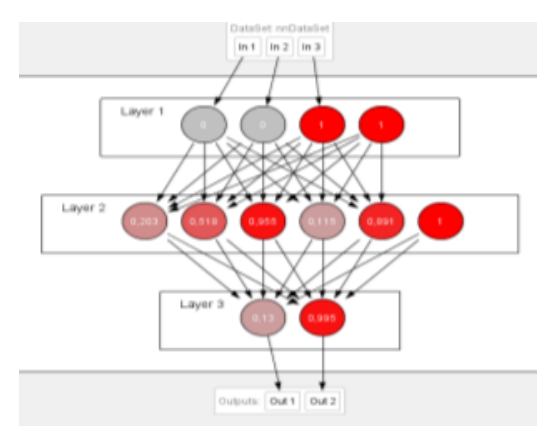

Gambar 5a In 3 bernilai 1

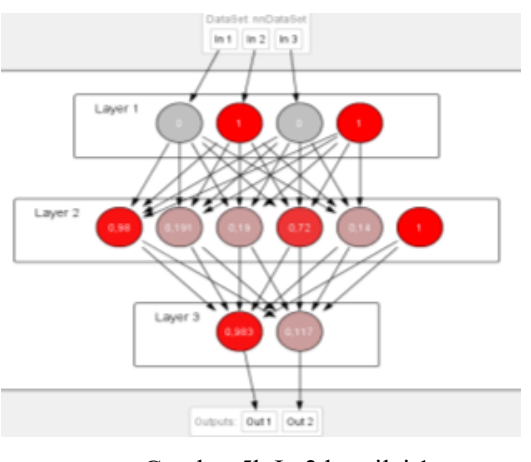

Gambar 5b In 2 bernilai 1

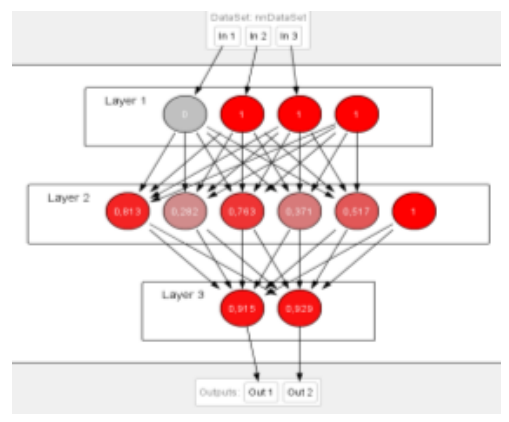

Gambar 5c In 2 dan 3 bernilai 1

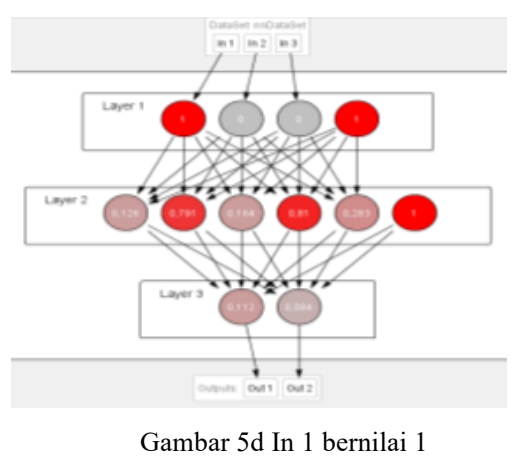

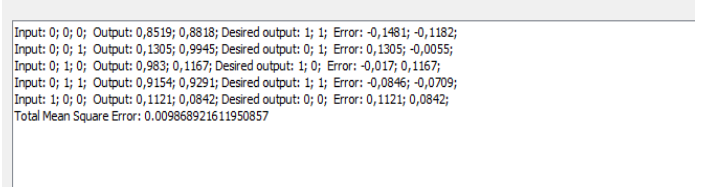

Gambar.6a Hasil Training Network Error

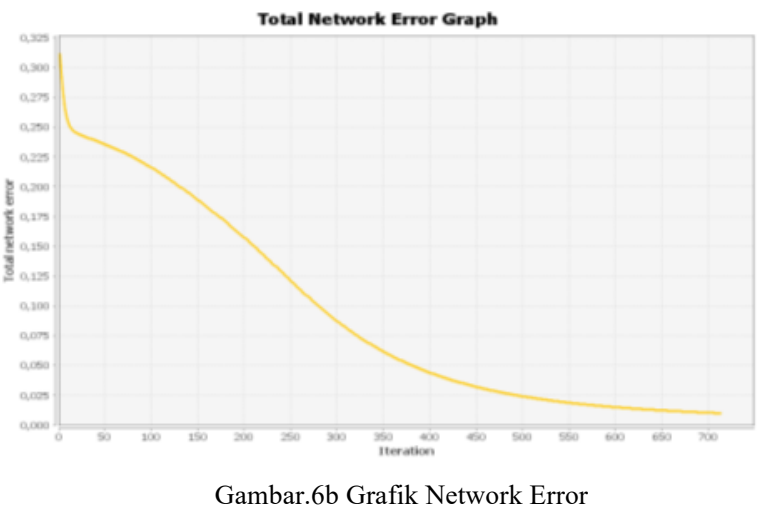

\subsection{Simulasi Mobotsim Mobile Robot}

Pada makalah ini, implementasi metode neural network yang digunakan terbukti dengan melakukan simulasi menggunakan aplikasi mobotsim (versi percobaan). Mobotsim adalah software 2D yang dapat dikonfigurasi menjadi simulator mobile robot yang memiliki antarmuka GUI dengan fitur lengkap untuk merancang robot dengan kecerdasan buatan seperti neural network dan fuzzy logic.

Mobile robot ini di program mengejar target dengan mengggunakan algoritma neural network, dimana target yang dimaksud adalah tanaman. Skenario yang dibuat untuk mobile robot ini mengejar 3 target dalam satu kali putaran setelah itu kembali ke posisi akhir. Mobile robot menggunakan 3 sensor jarak yang ditugaskan untuk menghindari rintangan dan mendeteksi target.

Pada (Gambar 7a) memperlihatkan posisi start mobile robot dan (Gambar.7i) memperlihatkan posisi finish mobile robot dalam 41,6s. Pada (Gambar 7b) memperlihatkan pergerakan mobile robot saat menuju ke target 1 lalu (Gambar 7c) memperlihatkan mobile robot sudah sampai di target 1 dalam $8,5 \mathrm{~s}$. Pada (Gambar 7d) memperlihatkan pergerakan mobile robot saat menuju ke target 2 lalu (Gambar.7e) memperlihatkan mobile robot sudah sampai di target 2 dalam 18,3s. Pada (Gambar 7f) memperlihatkan pergerakan mobile robot saat menuju ke target 3 lalu (Gambar 7g) Setelah training neural network, kita klik 'Tes' di memperlihatkan mobile robot sudah sampai di target 3 aplikasi neuroph, untuk melihat kesalahan total, dan dalam 26,7s. Dan (Gambar 7h) memperlihatkan semua kesalahan individu. Pada (Gambar 6a) pergerakan mobile robot saat menuju keposisi finish.

memperlihatkan hasil training untuk melihat kesalahan total dan semua kesalahan individu yang terjadi. Hasil total mean square error adalah 0,009868921611950857. Total mean square error ini berfungsi untuk mengetahui hasil error gerak robot dalam mencapai target tersebut. Hasil ini baik dan menunjukkan pilihan metode yang efektif sebagai parameter pembelajaran. Pada (Gambar 6b) memperlihatkan total grafik network error yang menampilkan grafik menurun.

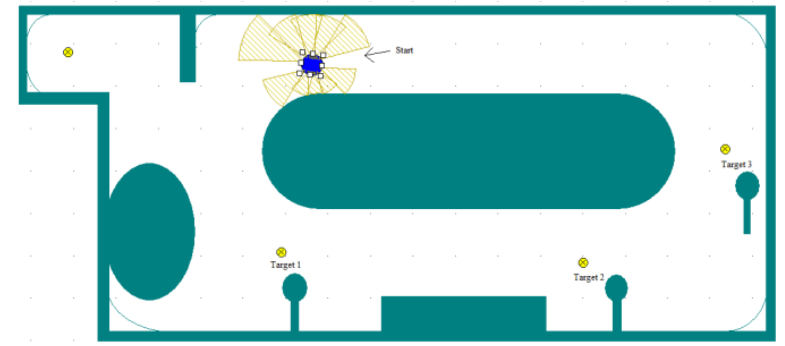




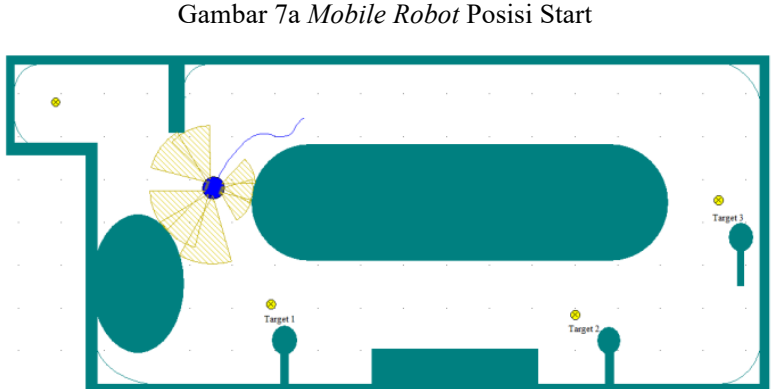

Gambar 7b Mobile Robot Menuju Target 1

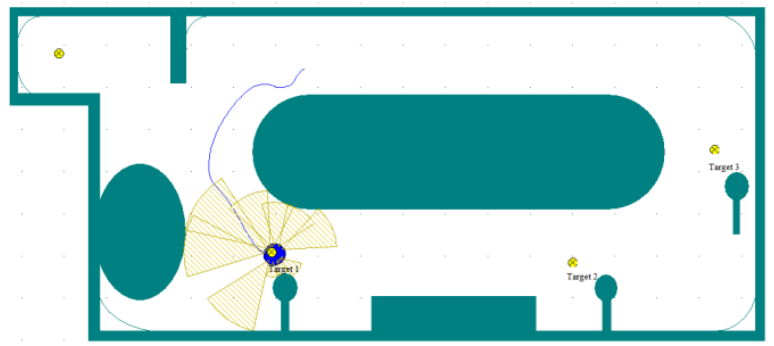

Gambar 7c Mobile Robot Sampai Target 1

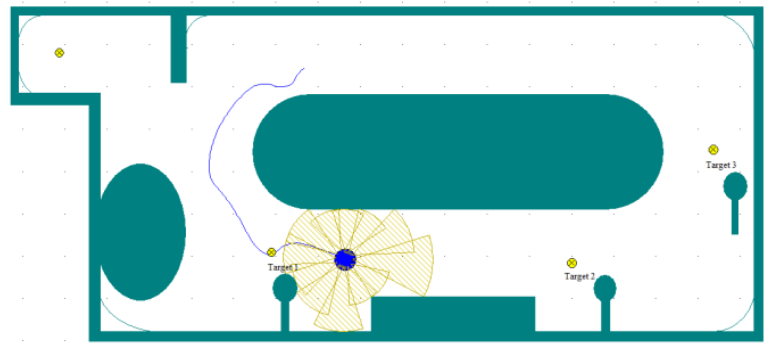

Gambar 7d Mobile Robot Menuju Target 2

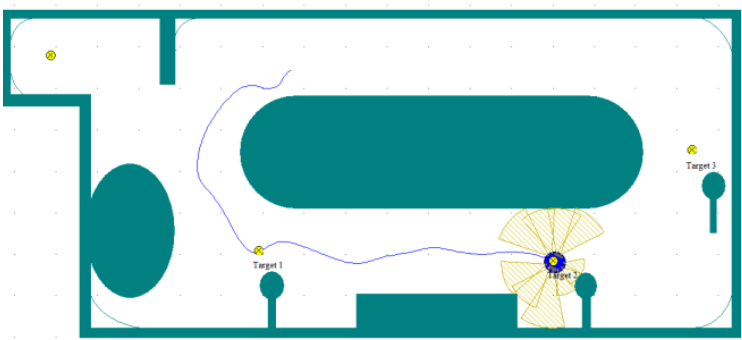

Gambar 7e Mobile Robot Sampai Target 2

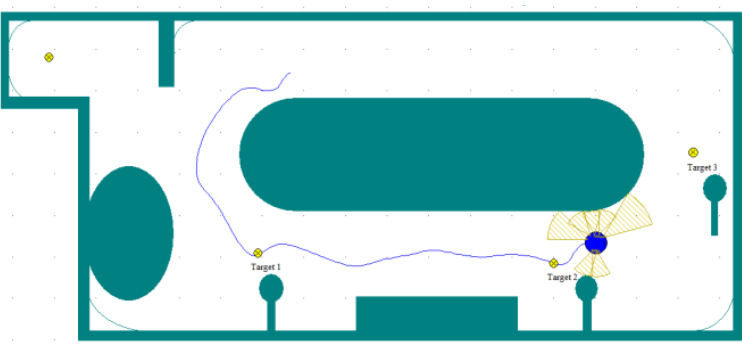

Gambar 7f Mobile Robot Menuju Target 3

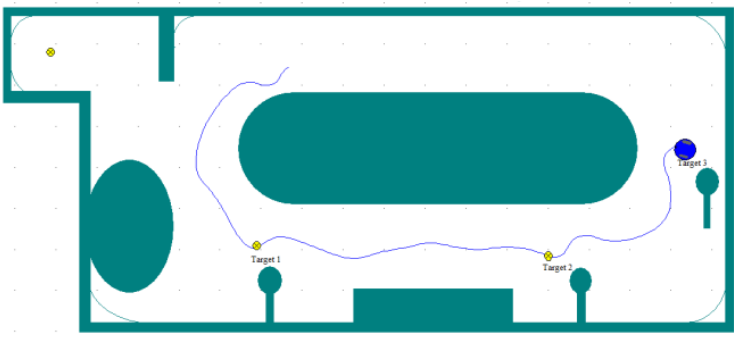

Gambar 7g Mobile Robot Sampai Target 3

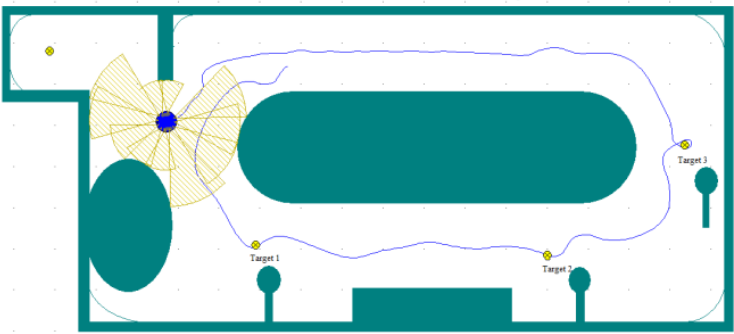

Gambar 7h Mobile Robot Menuju Posisi Finish

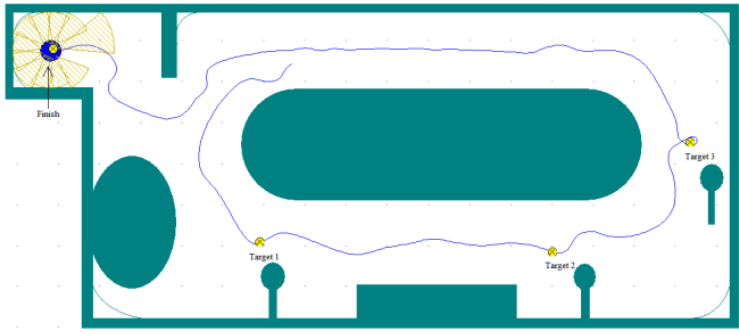

Gambar 7i Mobile Robot Posisi Finish

\section{Kesimpulan}

Dari penelitian yang kita telah lakukan ini, mobile robot pembasmi hama ini dibuat bertujuan untuk membantu para petani mengatasi serangan hama. Dalam penerapannya di lingkungan tidak tentu pergerakan mobile robot ini sering terjadi masalah. Maka dengan implementasi metode neural network untuk kendali gerak mobile robot pembasmi hama dengan lintasan tidak tentu ini dapat menghasilkan pengambilan keputusan pergerakan mobile robot yang efektif. Efektivitas dilihat dari nilai error mobile robot kurang dari 0,1 untuk menghindari rintangan yang ada didepannya dan sampai kepada target (tanaman) yang dituju untuk menyemprot pestisida.

\section{Daftar Rujukan}

[1] Hendrix R., Owan P., Garbini J., and Devasia S., 2019. ContextSpecific Separable Gesture Selection for Control of a Robotic Manufacturing Assistant. IFAC PapersOnline, 51(34), pp. 89-96.

[2] Dewi T., Nurmaini S., Risma P., Oktarina Y., and Roriz M., 2019, Inverse Kinematic Analysis of 4 DOF Pick and Place Arm Robot Manipulator using Fuzzy Logic Controller, IJECE, 10(2), pp. 1376-1386. doi:10.11591/ijece.v10i2.pp1376-1386.

[3] Uchiyama N., Dewi T., and Sano S., 2014, Collision Avoidance Control for a Human-Operated Four Wheeled Mobile Robot, Proceedings of the Institution of Mechanical Engineers, Part C: Journal of Mechanical Engineering Science, 228(13), pp. 22782284. https://doi.org/10.1177/0954406213518523.

[4] Dewi T., Amperawan, Risma P., Oktarina Y., and Yudha D. A., 2020, Finger Cue for Mobile Robot Motion Control, Computer 
Engineering and Application Journal, 9(1), pp. 39-48. doi: 10.18495/COMENGAPP.V9I1.319.

[5] Oktarina Y., Dewi T., and Risma T., 2020, The Concept of Automatic Transport System Utilizing Weight Sensor, 9(2), pp. 155-163. doi:10.18495/COMENGAPP.V0I0.339

[6] Dewi T., Risma P., Taqwa A., Rusdianasari, and Renaldi H., 2020 , Experimental analysis on solar powered mobile robot as the prototype for environmentally friendly automated transportation, Proc. iCAST on Engineering Science, 24-25 Oct 2019, Bali: Indonesia, doi:10.1088/1742-6596/1450/1/012034.

[7] Farooq U., Amar M., Asad M.U., Hanif A., and Saleh S.O., 2014. Design and Implementation of Neural Network of Based Controller for Mobile Robot Navigation in Unknown Environment. International Journal of Computer and Electrical Engineering, 6(2), pp. 83-89. doi:10.7763/IJCEE.2014.V6.799

[8] Uchiyama N., Dewi T., Sano S., and Takahashi H., 2014, Swarm Robot Control for Human Services and Moving Rehabilitation by Sensor Fusion, Journal of Robotics, 2014(278659), 11 pages. https://doi.org/10.1155/2014/278659.

[9] Al Yahmedi A.S., and Fatmi M.A., 2016. Fuzzy Logic Based Navigation of Mobile Robots," Intech, 6, pp. 111-133.

[10] Nurmaini S., Tutuko B., Dewi K., Yuliza V., and Dewi T., 2017, Improving Posture Accuracy of Non-holonomic Mobile Robot system with Variable Universe of Discourse, TELKOMNIKA, 15(3). Pp. 1265-1279. doi: 10.12928/TELKOMNIKA.v15i3.6078.

[11] Dewi T., Wijanarko Y., Risma P., and Oktarina Y., 2018, Fuzzy Logic Controller Design for Leader-Follower Robot Navigation, $5^{\text {th }}$ Proc. EECSI, 5(1), pp. 298-303. 16-18 Oct 2018, Malang : Indonesia. doi:10.1109/EECSI.2018.8752696.

[12] Dewi T., Risma P., and Oktarina Y., 2018, Fuzzy Logic Simulation as a Teaching-learning Media for Artificial Intelligence Class, Journal of Automation Mobile Robotics and Intelligent Systems, 12(3), pp. 3-9.doi: 10.14313/JAMRIS 3$\underline{2018 / 13}$

[13] Dewi T., Oktarina Y., Risma P., and Kartini S., 2019, Desain Robot PengikutManusiaSederhanadengan Fuzzy Logic Controller, Proc. Annual Research Seminar (ARS), 5(1), pp. 1216, 16 Nov 2019, Palembang: Indonesia.

[14] Oktarina Y., Septiarini F., Dewi T., Risma P., and Nawawi M., 2019, Fuzzy-PID Controller Design of 4 DOF Industrial Arm
Robot Manipulator, Computer Engineering and Application Journal, $8(2), \quad$ pp. 123-136. doi: 10.18495/COMENGAPP.V8I2.300.

15] Dewi T., Sitompul C., Risma P., Oktarina Y., Jelista R., Mulyati M., 2019, Simulation Analysis of Formation Control Design of Leader-Follower Robot Using Fuzzy Logic Controller, Proc 2019 ICECOS, 2-3 Oct. 2019, Batam Island: Indonesia. doi:10.1109/ICECOS47637.2019.8984433

[16] Yudha H. M., Dewi T., Hasana N., Risma P., Oktarina, Y. Kartini S., 2019, Performance Comparison of Fuzzy Logic and Neural Network Design for Mobile Robot Navigation, Proc. 2019 ICECOS, 2-3 Oct. 2019, Batam Island: Indonesia. doi:10.1109/ICECOS47637.2019.8984577

17] Larasati N., Dewi T., and Oktarina Y., 2017. Object Following Design for a Mobile Robot using Neural Network. Computer Engineering and Application Journal, 6(1), pp. 5-14. doi:10.18495/COMENGAPP.V6I1.189.

[18] Dewi T., Risma P., Oktarina Y., and Roseno M.T., 2017. Neural Network Design for a Mobile Robot Navigation a Case Study. 4th Proc. EECSI. 23-24 Sep. 2017. Yogyakarta: Indonesia. doi:10.1109/EECSI.2017.8239168.

[19] Dewi T., Risma P., Oktarina Y., and Nawawi M., 2017. Neural Network Simulation for Obstacle Avoidance and Wall Follower Robot as a Helping Tool for Teaching-Learning Process in Classroom. 1st Proc. ICEAT, 29-30 November 2017, Mataram: Indonesia. doi:10.1088/1757-899X/403/1/012043

[20] Risma P., Dewi T., Oktarina Y., and Wijanarko Y., 2019. Neural Network Controller Application on a Visual based Object Tracking and Following Robot. Computer Engineering and Application Journal, $8(1) . \quad$ doi: 10.18495/COMENGAPP.V8I1.280.

21] Kuswad S., Natasya A., Tamara M.N., and Adji I., 2018. Optimasi Sistem Navigasi Robot Bencana Dengan Algoritma Bug Dan Jaringan Syaraf Tiruan. JTIIK, . 5(5), pp. 635-642.

22] Savage J., Muoz S., Matamoros M., and Osorio R., 2013 Obstacle Avoidance Behaviors for Mobile Robots Using Genetic Algorithms and Recurrent Neural Networks. IFAC, 46(24), pp. 141146. 